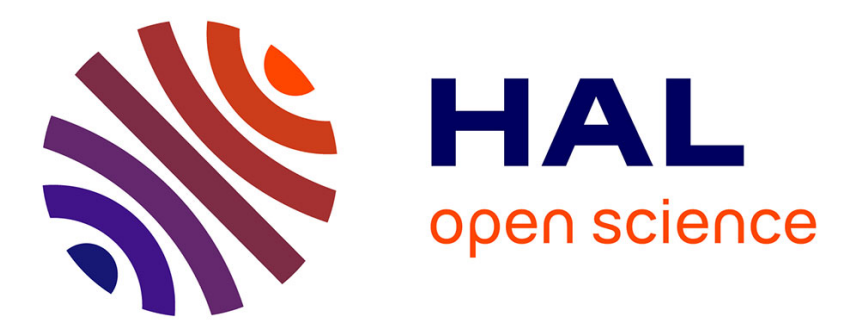

\title{
Relative abundances of methane- and sulfur-oxidizing symbionts in gills of the deep-sea hydrothermal vent mussel Bathymodiolus azoricus under pressure
} Kamil M. Szafranski, Bérénice Piquet, Bruce Shillito, François Lallier, Sébastien Duperron

\section{To cite this version:}

Kamil M. Szafranski, Bérénice Piquet, Bruce Shillito, François Lallier, Sébastien Duperron. Relative abundances of methane- and sulfur-oxidizing symbionts in gills of the deep-sea hydrothermal vent mussel Bathymodiolus azoricus under pressure. Deep Sea Research Part I: Oceanographic Research Papers, 2015, 101, pp.7-13. 10.1016/j.dsr.2015.03.003 . hal-01133684

\section{HAL Id: hal-01133684 \\ https://hal.sorbonne-universite.fr/hal-01133684}

Submitted on 20 Mar 2015

HAL is a multi-disciplinary open access archive for the deposit and dissemination of scientific research documents, whether they are published or not. The documents may come from teaching and research institutions in France or abroad, or from public or private research centers.
L'archive ouverte pluridisciplinaire HAL, est destinée au dépôt et à la diffusion de documents scientifiques de niveau recherche, publiés ou non, émanant des établissements d'enseignement et de recherche français ou étrangers, des laboratoires publics ou privés. 
1 Relative abundances of methane- and sulfur-oxidizing symbionts in gills of the deep-sea

2 hydrothermal vent mussel Bathymodiolus azoricus under pressure.

4 Kamil M. Szafranski ${ }^{1,2 *}$, Bérénice Piquet ${ }^{1,2}$, Bruce Shillito ${ }^{1,2}$, François H. Lallier ${ }^{3,4}$ and Sébastien

5 Duperron ${ }^{1,2,5}$

61 Sorbonne Universités, UPMC Univ Paris 06, UMR 7208, Adaptation aux Milieux Extrêmes 7 Paris, France

82 UMR MNHN UPMC CNRS IRD UCBN 7208 Biologie des Organismes Aquatiques et 9 Ecosystèmes, 75005 Paris, France

103 Sorbonne Universités, UPMC Univ Paris 06, UMR 7144, Equipe ABICE, Station Biologique de

11 Roscoff, 29680 Roscoff, France

124 CNRS, UMR 7144, Adaptation et Diversité en Milieu Marin, Station Biologique de Roscoff, 1329680 Roscoff, France

145 Institut Universitaire de France, Paris, France

$15 *$ Corresponding author: km.szafranski@gmail.com

16 Present address: Université Paris-Sud,

17 Unité d'Ecologie, Systématique et Evolution, CNRS UMR 8079

1891405 Orsay cedex, France

19 Phone: $+33(0) 169156115$

20

21 Running title: Symbiont abundances in Bathymodiolus azoricus under pressure

22 Keywords: 3D FISH; hydrothermal vents; pressurized recovery; symbiosis; symbiont 23 quantification; mussels 


\section{Abstract}

25 The deep-sea mussel Bathymodiolus azoricus dominates hydrothermal vent fauna in the the Azores

26 region. The gills of this species house methane- and sulfur-oxidizing bacteria that fulfill most of the 27 mussel's nutritional requirements. Previous studies suggested that the ratio between methane- and 28 sulfur-oxidizers could vary in response to the availability of electron donors in their environment, 29 and this flexibility is considered a key factor in explaining the ecological success of the species. 30 However, previous studies were based on non-isobaric recovery of specimens, with experiments at 31 atmospheric pressure which may have induced artifacts. This study investigates the effect of 32 pressure-related stress during recovery and experimentation on the relative abundances of bacterial 33 symbionts. Mussel specimens were recovered for the first time using the pressure-maintaining 34 device PERISCOP. Specimens were subsequently transferred into pressurized vessels and exposed 35 to various chemical conditions. Using optimized fluorescence in situ hybridization-based 36 approaches, relative abundance of symbionts were measured. Our results show that the recovery 37 method (isobaric versus non-isobaric) does not influence the abundances of bacterial symbionts. 38 Significant differences occur among specimens sampled from two contrasting sites. Exposure of 39 mussels from the deeper site to sulfide and bicarbonate, and to bicarbonate alone, both resulted in a 40 rapid and significant increase in the relative abundance of sulfur-oxidizers. Results reported herein 41 are congruent with those from previous reports investigating mussels originating from shallow sites 42 and kept at ambient pressure. Isobaric recovery and maintenance allowed us to perform in vivo 43 experiments in specimens from a deeper site that could not be maintained alive at ambient pressure, 44 and will greatly improve the chances of identifying the molecular mechanisms underlying the 45 dialogue between bathymodioline hosts and symbionts. 
47 Bathymodiolinae mussels (family Mytilidae) are part of the remarkable fauna colonizing ecosystems such as hydrothermal vents and cold seeps in the deep-sea (Desbruyères et al., 2000; Duperron, 2010; Duperron et al., 2009; von Cosel et al., 1999, 2001). These mussels rely upon sulfur- or methane-oxidizing (SOX and MOX) bacteria occurring in their gill epithelial cells for all or part of their nutrition (Cavanaugh et al., 1981; Felbeck, 1981). The symbionts of mussels exploit compounds present in vent or seep fluids for their metabolism (Van Dover, 2000; Van Dover et al., 2002). Although sulfide is toxic to animals, symbiotic sulfur-oxidizers use hydrogen sulfide from the fluids as the source of energy for their metabolism and to fix inorganic carbon (Cavanaugh et al., 1988). Methane-oxidizing bacteria use methane both as a carbon and an energy source (Cavanaugh et al., 1992; Childress et al., 1986). Organic carbon compounds are subsequently transferred to their animal host and ultimately contribute to ecosystem productivity in habitats where only a small fraction of the photosynthetic primary production from upper layers of the oceans is brought in by sedimentation or advective transport (Cavanaugh, 1983; Corliss et al., 1979; Karl et al., 1980).

Bathymodiolus azoricus and its sister species B. puteoserpentis dominate several vent sites on the Mid-Atlantic Ridge (MAR). They possess both sulfur- and methane-oxidizing symbionts in their gill bacteriocytes, as demonstrated through ultrastructural studies, 16S rRNA-encoding gene sequence analyses, and enzyme assays (Cavanaugh et al., 1992; Distel et al., 1995; Duperron et al., 2006; Fiala-Medioni et al., 2002; Fisher et al., 1993). Dual symbiosis is thought to increase the environmental tolerance of hosts because the distinct metabolism of the sulfur- and methaneoxidizing symbionts may help the holobiont adapt to varying availability of reduced sulfur and methane (Distel et al., 1995; Fiala-Medioni et al., 2002). Several studies point to a high flexibility of the symbiont populations (Kádár et al., 2005; Riou et al., 2008). Bacteria indeed disappear from B. azoricus gill bacteriocytes when subjected to starvation in sulfide- and methane-free sea-water, but can be recovered when mussels return to sulfide-enriched aquaria (Kádár et al., 2005). The relative volume occupied by each symbiont type in bacteriocytes of B. azoricus varies within vent sites, and between sites displaying different chemical signatures (Halary et al., 2008). Experiments using mussels maintained in controlled conditions at atmospheric pressure with one, both or none of the electron donors necessary for endosymbiont metabolism confirm that symbiont relative abundances can change rapidly in response to changes in the availability of their respective substrates (Halary et al., 2008; Riou et al., 2010, 2008).

However, the previously mentioned results suffer numerous potential biases. First, specimen recovery from the MAR vent sites, which are located at depths between $800 \mathrm{~m}$ (Menez Gwen) and 
$3500 \mathrm{~m}$ (Logatchev), involved rapid (usually a few hours) and large de-pressurization of specimens (8 to $35 \mathrm{MPa}$ ). This results in high levels of stress, ultimately resulting in the death of specimens from the deepest sites (Halary et al., 2008). Second, specimens used in in vivo experiments are usually from shallower vent sites (Menez Gwen) and maintained in the laboratory at atmospheric pressure, i. e. 80-fold lower than in situ conditions (Kádár et al., 2005; Riou et al., 2008). Results from these studies are thus potentially affected by artifacts associated with depressurization, and it remains to be confirmed whether observed symbiont dynamics were the consequence of these stresses or true biological responses. Another issue is with the quantification of symbionts itself. Several studies are based on a 3D fluorescence in situ hybridization (FISH) approach, which measures the fraction of the total volume occupied by each type of symbiont within bacteriocytes (Halary et al., 2008; Riou et al, 2008; Duperron et al, 2011). Although reliable, this approach is time consuming because it involves the acquisition of 3D images of gill sections, manual cropping of individual bacteriocytes, and computing volumes using a dedicated ImageJ plugin (Halary et al., 2008). This has limited the number of specimens that could be analyzed, reducing the statistical power of comparisons (Prosser, 2010).

Several pressurized vessels for live maintenance and pressurized recovery that prevent or reduce pressure-related stress have become available in recent years (Boutet et al., 2009). The first aim of the present study is to investigate relative symbiont abundances in B. azoricus mussels recovered from the Menez Gwen (800 m depth) and Rainbow (2300 m depth) vent sites using the pressuremaintaining PERISCOP sampling cell (Shillito et al., 2008). The second aim is to investigate these abundances in Rainbow specimens exposed to substrates used by the sulfide-oxidizing bacteria at their native pressure in the IPOCAMP vessel (Shillito et al., 2014). The percentage of total bacterial volume corresponding to methane- plus sulfur-oxidizing symbionts is measured by means of FISH and image analysis. In order to optimize the method, we compare results from three FISH-based approaches, and images acquired from the anterior and posterior regions of the gills. We then compare isobaric vs. non-isobaric recovery, Menez Gwen and Rainbow specimens, and the effect of treatments applied to live specimens from Rainbow. Results are discussed in relation to improvements of the methods used to investigate symbiont dynamics in animal tissue in light of previous reports, based on specimens from non-isobaric recoveries and exposed to various experimental conditions at atmospheric pressure.

\section{Material and methods}

\section{Sampling sites}

Bathymodiolus azoricus mussels (Bivalvia, Mytilidae) (von Cosel et al., 2001) were collected from two hydrothermal vent sites during the 2013 BioBaz cruise to the Mid-Atlantic Ridge aboard RV 
114 Pourquoi Pas? using the ROV Victor 6000. Specimens were sampled from the vicinity of active 115 smokers at Menez Gwen (MG2 marker, 3750.669' N 31 $31.156^{\prime} \mathrm{W}, 830 \mathrm{~m}$ depth) and Rainbow 116 (France5 marker, 36¹3.766' N 3354.117' W, $2270 \mathrm{~m}$ depth) (Figure 1). Active vents were 117 colonized by fauna typical for MAR vents, including one bivalve (Bathymodiolus azoricus) and 118 three shrimp species (Rimicaris exoculata, Mirocaris fortunata and Chorocaris chacei) 119 (Desbruyères et al., 2001).

\section{Isobaric and non-isobaric recovery}

121 At each sampling site, specimens were recovered in clean watertight BioBoxes, which were brought 122 to the surface by the ROV or the shuttle within a few hours (non-isobaric sampling). Others were 123 placed inside a 'CROCO' sampling cell that was fit into the pressure-keeping vessel PERISCOP 124 (isobaric recovery, Shillito et al., 2008). PERISCOP was then closed and the shuttle to which it was attached was released within a few minutes, and surfaced within 45 minutes. Pressure was monitored during surfacing with autonomous pressure sensor (SP2T4000, NKE Instruments, France). Once onboard, PERISCOP was opened and mussels were recovered and either dissected and fixed, or transferred to the IPOCAMP pressure vessel within 10 minutes.

\section{Exposure to bicarbonate and sulfide in pressurized vessels}

130 Six mussels from Rainbow, recovered using the PERISCOP, were taken out and used in incubation 131 experiments (shell length: 44.4-100.5 mm). Due to the limited volume of the IPOCAMP chamber 132 and the size of specimens, only two specimens were transferred in each of three 1 liter Nalgene ${ }^{\mathrm{TM}}$ 133 bottles filled with $11.8 \mu \mathrm{M} \mathrm{NaHCO}$ and $36.4 \mu \mathrm{M} \mathrm{Na} 2 \mathrm{~S}$; with $11.8 \mu \mathrm{M} \mathrm{NaHCO}_{3}$; or with filtered 134 sea-water alone (control). These concentrations were within the range of values recorded in mussel 135 aggregates on the site, and similar to values used in previous studies (Halary et al., 2008; Riou et al, 136 2008). Bottles were tightly closed and re-pressurized in IPOCAMP aquariums within 5 minutes.

137 Mussels were incubated at $23 \mathrm{MPa}$ and $8^{\circ} \mathrm{C}$ for $5 \mathrm{~h}$, then dissected immediately and fixed.

\section{Sample fixation onboard}

139 Anterior and posterior parts of mussel gill tissue were dissected at $4{ }^{\circ} \mathrm{C}$ and fixed for fluorescence in 140 situ hybridization (FISH). Gill fragments were transferred to $4 \%$ formaldehyde in twice-filtered sea141 water (TFSW) $\left(4^{\circ} \mathrm{C}, 2-4 \mathrm{~h}\right)$, rinsed, and dehydrated in increasing ethanol (50, 70 80, and 96\%, 15 142 min each). The density of gill filaments per millimeter was measured under a dissecting 143 microscope.

\section{Fluorescence in situ hybridization (FISH)}

145 Fragments of gills were embedded in polyethylene glycol distearate (PEG):1-hexadecanol (9:1), cut 146 into $8 \mu \mathrm{m}$-thick sections and deposited on SuperFrost Plus slides (VWR International, USA). Wax 
147 was removed and tissue rehydrated in decreasing ethanol series (96\% to 70\%). Sections were

148 hybridized using $40 \%$ formamide for $1-3 \mathrm{~h}$ at $46^{\circ} \mathrm{C}$ as previously described (Duperron et al., 2008),

149 rinsed, and mounted in DAPI-containing "Slow Fade" (Life Technologies) under a coverslip. Three

150 16S rRNA-specific probes were applied simultaneously on every section. FISH probes used are

151 summarized in Table 1.

152 Image acquisition and analysis

153 Slides were observed under a BX61 epifluorescence (Olympus, Japan) or a SP5 confocal (Leica, 154 Germany) microscope, and images were acquired at 400x magnification using ImagePro 6.0 155 (Olympus, Japan). On each section, a 2D image was first acquired by overlaying signals from the 156 three probe-associated fluorochromes (2D acquisition). Second, an image stack was built by 157 acquiring images every $0.3 \mu \mathrm{m}$ over the thickness of the section (3D acquisition). Images were 158 analyzed using ImageJ (Abramoff et al., 2004) and the total volume occupied by bacteria and 159 respective proportions of the sulfur- and methane-oxidizing symbionts were computed for 2D and 160 3D images using the SymbiontJ plug-in as previously described, but applying the procedure to the 161 whole field of view without isolating individual bacteriocytes (Halary et al., 2008). SymbiontJ 162 applies filters and thresholds to the different color channels and computes the number of voxels 163 corresponding to each symbiont type. Finally, ten bacteriocytes were manually cropped from each $1643 \mathrm{D}$ acquisition, analyzed using SymbiontJ, and the mean percentage of volume occupied by each 165 bacterial type was computed (bacteriocyte acquisition).

166 Statistical analyses

167 The percentage of bacterial volume occupied by methane-oxidizing bacteria was used for all 168 analyses, after an Arcsine transformation (Halary et al., 2008). Values were then used for 169 transformation-based redundancy analyses (tb-RDA). Sampling site (Menez Gwen versus 170 Rainbow), recovery mode (isobaric versus non-isobaric), acquisition method (2D, 3D or 171 bacteriocyte), gill region (anterior versus posterior), and specimen were used as factors into the 172 constrained redundancy analysis (RDA), in order to estimate their contribution to the global 173 variance. Significance was assessed using permutation tests (n=9999) using a full model, with 174 separate test for each term (constraining variable). Shapiro-Wilk tests revealed non-normal 175 distribution of the data, and non-parametric tests were thus applied for inter-groups comparisons. 176 The Mann-Whitney-Wilcoxon (MWW, for 2 class factors) and Kruskal-Wallis (KW, for 3 or more 177 class factors) tests were used to compare percentages of methanotrophs. All statistical analyses were 178 performed using R (R Development Core Team, 2013); 'vegan' package was used for the 179 constrained redundancy analysis. 
181 In order to optimize the 3D FISH method (Halary et al., 2008), three types of images were acquired 182 and compared. For each mussel specimen, 10 acquisitions in 2D and 10 in 3D were obtained. From 183 each of the later 3D acquisitions, 10 randomly chosen bacteriocytes were analyzed, resulting in 100 184 bacteriocytes per specimen. These acquisitions were obtained from at least 5 different sections, each 185 containing 10-20 filaments. Results are summarized in Table 2, and a micrograph showing gill 186 tissue with bacteriocytes containing the two symbionts is presented on Figure 2. The analyses of 187 2D, 3D, and bacteriocytes did not yield significantly different results (KW test on all measurements 188 including anterior and posterior gill regions, $\mathrm{p}$-value $=0.09$ ).

189 The filament density per mm gill length along the anterior-posterior axis decreased significantly 190 with increasing shell length $\left(\mathrm{R}^{2}=65 \%\right.$, Pearson's correlation test: $\mathrm{p}$-value < 0.001 , Figure 3$)$. Gills 191 form and grow from the posterior end. Percentages of methanotrophs (MOX) in the anterior and 192 posterior regions of gill from 3 specimens per treatment (12 specimens) were computed using 2D 193 and 3D methods, yielding in total 480 measurements (Table 2, Table S1). The percentage of volume 194 occupied by methanotrophs was not significantly different between anterior and posterior regions of 195 the gills (MWW test, p-value $=0.64$ ). Subsequent analyses were thus made only on the anterior part 196 of gills, for which more specimens were available.

197 When recovered in BioBoxes, mussels from Menez Gwen and Rainbow experienced pressure loss 198 of around 8.3 and $23 \mathrm{MPa}$, respectively. The use of PERISCOP prevented that, and mussels arrived 199 onboard at pressures close to those of the deep waters (Table 2). Percentages of volume occupied by 200 methanotrophs were $46.5 \% \pm 5.8$ and $56.3 \% \pm 6.4$ in Menez Gwen and Rainbow mussels recovered 201 in BioBoxes, and 44.3\% \pm 5.7 and 56.3\% \pm 8.3 in mussels recovered using PERISCOP (Figure 4, 202 Table 2). A MWW test based on 1140 values from the anterior and posterior regions of the gills 203 indicated no significant difference between the two types of recovery ( $p$-value $=0.12$ ).

204 Mussels from Menez Gwen and Rainbow sites displayed significantly different percentages of 205 methanotrophs in their gills (MWW test, $\mathrm{W}=36185.5$, p-value $<2.2 \mathrm{e}-16$ ). A unilateral test 206 confirmed that methanotrophs occupied a higher fraction of the overall volume in bacteriocytes of 207 B. azoricus from the deeper Rainbow site (Figure 4, Table 2, Table S1).

208 The influence of each aforementioned factor was estimated by constrained redundancy analysis 209 (RDA) and ANOVA permutation tests. Overall, our model could explain $56 \%$ of the total variance. 210 Sampling site was the most influential factor $(41 \%$; $\mathrm{df}=1 ; \mathrm{F}=1026.1)$, followed by inter211 individual differences, which accounted for more than $14 \%(\mathrm{df}=27 ; \mathrm{F}=13.3)$ of the total variance. 212 Other factors explained much lower fractions of the variance: recovery mode $(0.3 \%$; $\mathrm{df}=1 ; \mathrm{F}=$ 213 7.7), acquisition method $(0.3 \% ; \mathrm{df}=2 ; \mathrm{F}=3.8)$ and gill region $(0.04 \% ; \mathrm{df}=1 ; \mathrm{F}=0.1)$ (Table $\mathrm{S} 2)$.

214 Each experimental condition could be applied to 2 specimens only from Rainbow because of the 
215 limited volume of bottles and the limited number of bottles that could be incubated at once in

216 pressurized vessels. Nevertheless, 2 different treatments $\left(\mathrm{NaHCO}_{3}+\mathrm{Na}_{2} \mathrm{~S}\right.$ or $\mathrm{NaHCO}_{3}$ alone $)$ and 2

217 control experiments (10 mussels fixed immediately after recovery using PERISCOP and 2

218 incubated in filtered sea-water in the same conditions as above) were applied, and 320

219 measurements were made using 2D and 3D methodologies (Figure 5, Table S3). There was no

220 significant difference between 2D and 3D FISH acquisition methods in this dataset (MWW test, p-

221 value $=0.54)$. The different treatments under pressure resulted in significant differences in

222 percentages of methanotrophs (KW test, p-values $<0.011)$. The percentage of sulfur-oxidizers was

223 twice higher in specimens exposed to sulfide and bicarbonate than in the sea-water treatment, with

$22490.1 \% \pm 17.6$ versus 38.5\% \pm 4.9 (Figure 5, Table S3). Specimens exposed to bicarbonate alone

225 also displayed a markedly higher percentage of sulfur-oxidizers (SOX) than in the sea-water

226 treatment. SOX in the bicarbonate treatment occupied $76.0 \% \pm 23.0$ of the bacterial volume. The

227 percentage of SOX was slightly lower in mussels incubated in filtered seawater than prior to

228 treatments $(38.5 \pm 4.9$ versus $42.5 \% \pm 7.6)$. Constrained RDA indicated that the overall variance

229 was mainly explained by the 'treatment' factor $(68.5 \%$; $\mathrm{df}=3 ; \mathrm{F}=506.7)$ and by inter-individual

230 variability $(18 \% ; \mathrm{df}=12 ; \mathrm{F}=32.8)$, while $0.4 \%(\mathrm{df}=1 ; \mathrm{F}=0.9)$ was due to the method of image

231 acquisition (Table S4).

\section{Discussion}

233 Image based quantification of volumes occupied by symbionts

234 Three FISH approaches were applied in this study, based on acquisition of 2D (Figure 2A) and 3D 235 images, and of individual bacteriocytes (Figure 2B). They did not yield significantly different 236 results. Although the results are similar, the bacteriocyte-based method used in previous studies 237 (Riou et al., 2010) is by far the most time-consuming, because it involves manually cropping and 238 computing percentages of methanotrophs in at least 10 bacteriocytes from each 3D image. If the 239 aim is to maximize the number of acquisitions, the 2D or 3D approaches are equally suitable and far 240 less time-consuming. In this study we managed to analyze a total of 36 specimens with two to three 241 of these methods (Table 2), while previous studies using 3D-FISH were based 20 or fewer 242 individuals (Duperron et al., 2011, 2007; Halary et al., 2008; Lorion et al., 2012; Riou et al., 2010, 243 2008).

\section{Sampling methodology}

245 The density of gill filaments was negatively related to shell length, i.e. the longer the shell was, the 246 less dense gill filaments were (Figure 3). Similar filament densities and size-related trend are 247 reported for the mussel Mytilus edulis (Jones et al., 1992). The gill forms and grows from the 248 posterior end in bivalves (Cannuel et al., 2009; Wentrup et al., 2014); this process could result in 
differences in symbiont relative abundances between the 'young' posterior part and 'old' anterior one, but this was not confirmed by our data. It is likely that the absolute number of symbionts in each filament, which was not computed here, is different in the respective gill regions, in particular in the posterior-most budding zone (Wentrup et al., 2014). Measuring absolute numbers of symbionts would be necessary, but a reliable method still remains to be implemented (Boutet et al., 254 2011).

255 The two sites analyzed differed in depth (850 $\mathrm{m}$ at Menez Gwen and $2300 \mathrm{~m}$ at Rainbow) but non256 isobaric recovery in BioBoxes involved significant pressure loss and potential physiological stress 257 in both cases. Recovery stress is a major criticism often addressed to deep-sea biologists and 258 physiologists by many colleagues who are dubious about reports from ex situ experiments. In the 259 present study, mussels were for the first time recovered under their natural pressure until opening of 260 the PERISCOP vessel on board, and compared with specimens recovered using classical, non261 isobaric BioBoxes. Results indicate that, as far as symbiont relative abundances in gills are 262 concerned, the recovery mode did not have any significant influence, not even for the deeper 263 Rainbow site (Figure 4). This major finding validates a posteriori previous studies dealing with 264 symbiont relative abundances that did use classical non-isobaric recovery methods involving 265 pressure loss (Duperron et al., 2011, 2006; Halary et al., 2008; Lorion et al., 2012; Riou et al., 2010, 266 2008). However, although non-isobaric sampling is appropriate for studies focusing on symbiont 267 relative abundances, isobaric recovery probably makes a difference when dealing with 268 physiological parameters such as host and symbiont activities and gene expression. FISH signal 269 intensities (but not areas and volumes) were indeed usually higher in specimens recovered using 270 PERISCOP, suggesting that ribosomes to which FISH probes attach were less abundant in the latter 271 (unpublished data).

\section{Site-related differences in symbiont abundances}

273 Besides depth, the Menez Gwen and Rainbow sites differ by several characteristics, including the 274 chemical composition of end-member fluids. Fluids at Menez Gwen indeed display slightly lower 275 concentrations of methane compared to Rainbow (Charlou et al., 2002). Sulfide concentrations are 276 similar, but sulfide interacts with the high concentrations of iron at Rainbow, and is thus not readily 277 available to organisms (Desbruyères et al., 2000; Le Bris and Duperron, 2010). Geochemical 278 modeling applied to the mixing zone where mussels actually live indicate that more energy can be 279 gained from sulfide at Menez Gwen compared to methane, while the opposite situation is 280 encountered at Rainbow (Le Bris and Duperron, 2010). The result at Rainbow is however less clear281 cut when including hydrogen, an alternative energy source for sulfur-oxidizing symbionts (Petersen 282 et al., 2011). The ratio between sulfide and methane has been shown to influence the relative 
283 abundance of sulfur- versus methane-oxidizers in mussel gills, and methanotrophs are more

284 abundant than thiotrophs at Rainbow (Duperron et al., 2006). Previous estimations of symbiont 285 relative abundances indicated that sulfur-oxidizers represented $53.1 \% \pm 10.3$ of the total volume of 286 symbionts at Menez Gwen, compared to 39.4\% at Rainbow (Halary et al., 2008; Le Bris and 287 Duperron, 2010). Our results from PERISCOP-recovered specimens were remarkably close $(52.6 \%$ $288 \pm 4.9$ and $43.7 \% \pm 6.4$ respectively; Table 2$)$. This is in line with the hypothesis that symbiont 289 relative abundances depend on the availability of their respective substrates (Fiala-Medioni et al., 290 2002; Riou et al., 2008; Trask and Van Dover, 1999). Furthermore, the unexpected similarity 291 between measurements made on specimens sampled in 2006 and 2013 suggests a certain level of 292 long term stability in site-related differences, although short-term fluctuations certainly have 293 occurred (Duperron et al., 2006; Halary et al., 2008).

\section{Symbiont response to bicarbonate and sulfide pulses under pressure}

295 Starvation experiments and exposure to increased concentrations of different chemosynthesis 296 substrates have already been performed by several groups (Halary et al., 2008; Kádár et al., 2005; 297 Riou et al., 2008), but most often on B. azoricus from the shallower Menez Gwen site and at 298 ambient pressure. Here, we tested the effect of sulfide and bicarbonate exposure on pressurized $B$. 299 azoricus from the deeper Rainbow site (2300 m depth). Mussels from this site are not easily 300 maintained in the lab at ambient pressure (authors' personal observation). PERISCOP-recovered 301 mussels were transferred to pressure vessels and maintained at $8^{\circ} \mathrm{C}$ and $23 \mathrm{MPa}$. A 5h incubation 302 period with bicarbonate and sulfide resulted in doubling of the relative abundance of thiotrophs in 303 the gills (Figure 5). Exposure to bicarbonate alone also significantly increased the relative 304 abundance of thiotrophs (Figure 5). These rapid changes confirm that observations reported in 305 Halary et al. 2008 and other works on mussels from Menez Gwen were not artifacts, and not linked 306 to recovery stress or experimentation at atmospheric pressure. The increase in thiotroph relative 307 volume observed in the present study is even more spectacular (65.0\% in Halary et al., 2008). In 308 another study, mussels subjected to a one-month starvation followed by 4 days of constant sulfide 309 supply showed a 96\% bacterial volume occupation by thiotrophs (Riou et al., 2008). Here, we show 310 that non-starved B. azoricus can shift to an almost thiotrophic symbiosis within 5 hours of exposure 311 to sulfide and bicarbonate (Figure 5). Unfortunately, only two specimens could be subjected to each 312 treatment because of space limitations in IPOCAMP. So although the trend is clear, data from more 313 specimens is needed to reliably estimate the true amplitude of this effect. Thiotrophic symbionts fix 314 inorganic carbon using ribulose-1,5-bisphosphate Carboxylase Oxygenase (RubisCO) in the Calvin 315 cycle (Cavanaugh et al., 1988). This process requires energy from the oxidation of reduced sulfur 316 compounds (Cavanaugh et al., 1988). The less spectacular increase in relative abundance of 
317 thiotrophs when only bicarbonate was available also suggests that another source of energy may

318 have been used for chemosynthesis. Over a short period, bacteria might have used sulfur stored in 319 compounds such as taurine or thiotaurine (Pruski and Fiala-Médioni, 2003). Alternatively, 320 hydrogen, not measured in our study, has been demonstrated to be an alternative energy source for 321 hydrothermal vent symbioses (Amend and Shock, 2001; Petersen et al., 2011). Although the 322 increase in thiotrophs relative abundance could result directly from an actual increase in their 323 number, it could alternatively result from a decrease in methanotrophs, whose substrate was absent 324 and which may have been digested by host bacteriocytes before thiotrophs. Methanotrophs are 325 indeed located more basally within bacteriocytes, closer to phagolysosome-like bodies (Distel et al., 326 1995; Duperron et al., 2005). It is not known which mechanisms on the host and symbionts sides 327 control the dynamics of bacterial populations within bacteriocytes. Mussel symbionts have been 328 shown to divide and to be digested within bacteriocytes, but additional mechanisms may explain 329 their variations, including symbiont uptake from the environment by adults, as suggested in $B$. 330 brevior, and symbiont release as documented in corals (Dubilier et al., 1998; Lesser, 2011; Thurber 331 et al., 2009). Whatever the underlying mechanisms, the symbiont population as a whole seems to be 332 rapidly and significantly affected by changes in the availability of energy and carbon sources, 333 although results from more specimens are necessary.

\section{Conclusions}

335 In this study, a FISH-based method was used to quantify relative abundances of endosymbionts in 336 gills of Bathymodiolus azoricus. Abundances in the anterior and posterior regions of the gill were 337 similar. Mussels sampled in isobaric and non-isobaric recovery devices displayed similar relative 338 volumes of the two types of symbionts indicating that non-isobaric recovery does not induce a 339 major bias in measured volume occupation. However, the physiological status of mussels and their 340 endosymbionts is probably not the same and isobaric recovery is certainly to be recommended for 341 physiological or expression studies of specimens from the deepest sites. Symbiont relative volumes 342 were different between the Menez Gwen and Rainbow sites, and similar to those previously 343 measured on specimens sampled 7 years ago. On the other hand, symbiont populations displayed 344 high flexibility in exposure experiments performed in pressurized aquaria. As postulated previously, 345 this flexibility is certainly an advantage because physico-chemical micro-environments at 346 hydrothermal vents are highly variable in time and space (Chevaldonné et al., 1991; Johnson et al., 347 1994, 1986; Le Bris et al., 2005), and maybe the key for the domination of Bathymodiolus azoricus 348 at various hydrothermal vent sites of the Mid-Atlantic Ridge (Desbruyères et al., 2001, 2000; Von 349 Cosel et al., 1999). More experiments involving methane, hydrogen, toxic compounds, but also 350 thermal stress and symbiont release experiments will be necessary to further explore this flexibility. 
351 The next step will then be to unravel the mechanisms that control this flexibility by exploring cell

352 division patterns, genes and protein expressions of host and symbionts in various conditions.

\section{Acknowledgments}

354 We thank the captain and crew of RV "Pourquoi Pas?" and ROV "Victor 6000" for their invaluable 355 help onboard. We are grateful to M. Zbinden, J-Y. Collet, J-B. Collet and A. Tanguy for their help 356 with samples and aquaria onboard, and V. Le Layec for his help in the lab. This research was 357 supported by CNRS, UPMC, UCBN and ITN Symbiomics. K. Szafranski was funded through a 358 Ph.D. grant from the Marie Curie Actions Initial Training Network (ITN) SYMBIOMICS (contract 359 number 264774). The authors would like to thank the reviewers and editors for their comments that 360 helped to improve the manuscript.

\section{Table legends}

362 Table 1: Probes, target groups, and labels used in FISH experiments.

363 Table 2: Sites, number of individuals, and percentages of methane- (MOX), and sulfur-oxidizers 364 (SOX), standard deviation (SD) measured using the 2D, 3D, and bacteriocyte-based FISH methods 365 in the anterior region of the gill. Maintained pressure during recovery has been calculated as follow: $366 \mathrm{P}_{\min } / \mathrm{P}_{\max } \times 100 \%$, where $\mathrm{P}_{\max }$ is the pressure at sampling site, $\mathrm{P}_{\min }$ - the minimal pressure during 367 recovery.

368 Table S1: Sites, number of individuals, and percentages of methane- (MOX), and sulfur-oxidizers 369 (SOX), standard deviation (SD) measured using the 2D and 3D -based FISH methods in the 370 posterior region of the gill.

371 Table S2: Redundancy analysis estimating the contribution of factors site (SITE), recovery method 372 (REC), FISH method (METH), localization in the gill (GILL), and inter-individual variability 373 (IND) to the variability observed in percentages of methane-oxidizers in gills among Menez Gwen 374 and Rainbow specimens.

375 Table S3: Percentages of methane- (MOX), and sulfur-oxidizers (SOX) and standard deviation (SD) 376 measured using the 2D- and 3D -based FISH methods in the anterior region of the gill of Rainbow 377 specimens upon recovery using PERISCOP (T0) and those exposed to 5-hours experimental 378 treatments in pressurized vessels at $23 \mathrm{MPa}$.

379 Table S4: Redundancy analysis estimating the contribution of factors treatment (TREAT), FISH 380 method (METH), and inter-individual variability (IND) in the variance observed in percentages of 381 methane-oxidizers in gills among Rainbow specimens exposed to chemical treatments in 382 pressurized vessels. 
384 Figure 1: Localization of sampling sites on the Mid-Atlantic Ridge. MG - Menez Gwen site (830 m depth); Rb - Rainbow site (2270 m depth).

Figure 2: Overview (A) and detail (B) of transverse sections through B. azoricus gill filaments observed at 400x magnification. Filaments were cut parallel to the plane defined by the animals anterior-posterior and left-right axes, and perpendicular to its dorso-ventral axis. Nuclei from host tissue are labeled with DAPI (blue). FISH-labeled bacterial symbionts appear in pink (sulfuroxidizers) and green (methanotrophs).

Figure 3: Density of gill filaments versus antero-posterior length of the shell. Fitted line is a linear regression $\left(\mathrm{R}^{2}=65 \%\right.$, Pearson's correlation test: $\mathrm{p}$-value $\left.<0.001\right)$.

Figure 4: Mean percentage and standard deviation of total bacterial volume occupied by methaneoxidizers in gill tissue of B. azoricus specimens from Menez Gwen and Rainbow recovered in BioBoxes (non-isobaric) and PERISCOP vessels (isobaric). Shades of grey correspond to the three FISH methods as indicated (see text for details).

Figure 5: Mean percentage and standard deviation of total bacterial volume occupied by sulfuroxidizers in gill tissue of B. azoricus specimens from Rainbow upon recovery using PERISCOP (T0) and exposed to experimental treatments in pressurized vessels $\left(\mathrm{NaHCO}_{3}+\mathrm{Na}_{2} \mathrm{~S}, \mathrm{NaHCO}_{3}\right.$, filtered sea-water). Shades of grey correspond to the two FISH methods as indicated (see text for 401 details).

\section{References}

403

Abramoff, M., Magelhaes, P., Ram, S., 2004. Image Processing with ImageJ. Biophotonics Int. 11, $36-42$.

Amann, R.I., Binder, B.J., Olson, R.J., Chisholm, S.W., Devereux, R., Stahl, D.A., 1990. Combination of $16 \mathrm{~S}$ rRNA-targeted oligonucleotide probes with flow cytometry for analyzing mixed microbial populations. Appl. Environ. Microbiol. 56, 1919-1925.

Amend, J.P., Shock, E.L., 2001. Energetics of overall metabolic reactions of thermophilic and hyperthermophilic Archaea and Bacteria. FEMS Microbiol. Rev. 25, 175-243.

Boutet, I., Jollivet, D., Shillito, B., Moraga, D., Tanguy, A., 2009. Molecular identification of differentially regulated genes in the hydrothermal-vent species Bathymodiolus thermophilus and Paralvinella pandorae in response to temperature. BMC Genomics 10, 222.

Boutet, I., Ripp, R., Lecompte, O., Dossat, C., Corre, E., Tanguy, A., Lallier, F.H., 2011. Conjugating effects of symbionts and environmental factors on gene expression in deep-sea hydrothermal vent mussels. BMC Genomics 12, 530.

Cannuel, R., Beninger, P.G., McCombie, H., Boudry, P., 2009. Gill development and its functional and evolutionary implications in the blue mussel Mytilus edulis (Bivalvia: Mytilidae). Biol. Bull. 217, 173-188.

Cavanaugh, C.M., 1983. Symbiotic chemoautotrophic bacteria in marine invertebrates from sulphide-rich habitats. Nature 302, 58-61.

Cavanaugh, C.M., Abbott, M.S., Veenhuis, M., 1988. Immunochemical localization of ribulose-1,5- 
bisphosphate carboxylase in the symbiont-containing gills of Solemya velum (Bivalvia: Mollusca). Proc. Natl. Acad. Sci. U. S. A. 85, 7786-7789.

Cavanaugh, C.M., Gardiner, S.L., Jones, M.L., Jannasch, H.W., Waterbury, J.B., 1981. prokaryotic cells in the hydrothermal vent tube worm Riftia pachyptila Jones: possible chemoautotrophic symbionts. Science 213, 340-342.

Cavanaugh, C.M., Wirsen, C.O., Jannasch, H.W., 1992. Evidence for methylotrophic symbionts in a hydrothermal vent mussel (bivalvia: mytilidae) from the mid-atlantic ridge. Appl. Environ. Microbiol. 58, 3799-3803.

Charlou, J.L., Donval, J.P., Fouquet, Y., Jean-Baptiste, P., Holm, N., 2002. Geochemistry of high $\mathrm{H}_{2}$ and $\mathrm{CH}_{4}$ vent fluids issuing from ultramafic rocks at the Rainbow hydrothermal field (36²' 14 , MAR). Chem. Geol. 191, 345-359.

Chevaldonné, P., Desbruyères, D., Haître, M.L., 1991. Time-series of temperature from three deepsea hydrothermal vent sites. Deep Sea Res. Part Oceanogr. Res. Pap. 38, 1417-1430.

Childress, J.J., Fisher, C.R., Brooks, J.M., Kennicutt, M.C., Bidigare, R., Anderson, A.E., 1986. A methanotrophic marine molluscan (bivalvia, mytilidae) symbiosis: mussels fueled by gas. Science 233, 1306-1308.

Corliss, J.B., Dymond, J., Gordon, L.I., Edmond, J.M., Herzen, R.P. von, Ballard, R.D., Green, K., Williams, D., Bainbridge, A., Crane, K., Andel, T.H. van, 1979. Submarine Thermal Sprirngs on the Galápagos Rift. Science 203, 1073-1083.

Desbruyères, D., Almeida, A., Biscoito, M., Comtet, T., Khripounoff, A., Bris, N.L., Sarradin, P.M., Segonzac, M., 2000. A review of the distribution of hydrothermal vent communities along the northern Mid-Atlantic Ridge: dispersal vs. environmental controls. Hydrobiologia 440, 201-216.

Desbruyères, D., Biscoito, M., Caprais, J.-C., Colaço, A., Comtet, T., Crassous, P., Fouquet, Y., Khripounoff, A., Le Bris, N., Olu, K., Riso, R., Sarradin, P.-M., Segonzac, M., Vangriesheim, A., 2001. Variations in deep-sea hydrothermal vent communities on the MidAtlantic Ridge near the Azores plateau. Deep-Sea Res. I 48, 1325-1346.

Distel, D.L., Lee, H.K., Cavanaugh, C.M., 1995. Intracellular coexistence of methano- and thioautotrophic bacteria in a hydrothermal vent mussel. Proc. Natl. Acad. Sci. U. S. A. 92, 9598-9602.

Dubilier, N., Windoffer, R., Giere, O., 1998. Ultrastructure and stable carbon isotope composition of the hydrothermal vent mussels Bathymodiolus brevior and B. sp. affinis brevior from the North Fiji Basin, western Pacific. Mar. Ecol. Prog. Ser. 165, 187-193.

Duperron, S., 2010. The diversity of deep-sea mussels and their bacterial symbioses, in: Kiel, S. (Ed.), The Vent and Seep Biota, Topics in Geobiology. Springer Netherlands, pp. 137-167.

Duperron, S., Bergin, C., Zielinski, F., Blazejak, A., Pernthaler, A., McKiness, Z.P., DeChaine, E., Cavanaugh, C.M., Dubilier, N., 2006. A dual symbiosis shared by two mussel species, Bathymodiolus azoricus and Bathymodiolus puteoserpentis (Bivalvia: Mytilidae), from hydrothermal vents along the northern Mid-Atlantic Ridge. Environ. Microbiol. 8, 14411447.

Duperron, S., Guezi, H., Gaudron, S.M., Pop Ristova, P., Wenzhöfer, F., Boetius, A., 2011. Relative abundances of methane- and sulphur-oxidising symbionts in the gills of a cold seep mussel and link to their potential energy sources. Geobiology 9, 481-491.

Duperron, S., Laurent, M.C.Z., Gaill, F., Gros, O., 2008. Sulphur-oxidizing extracellular bacteria in the gills of Mytilidae associated with wood falls. FEMS Microbiol. Ecol. 63, 338-349.

Duperron, S., Lorion, J., Samadi, S., Gros, O., Gaill, F., 2009. Symbioses between deep-sea mussels (Mytilidae: Bathymodiolinae) and chemosynthetic bacteria: diversity, function and evolution. C. R. Biol. 332, 298-310.

Duperron, S., Nadalig, T., Caprais, J.C., Sibuet, M., Fiala-Medioni, A., Amann, R., Dubilier, N., 2005. Dual symbiosis in a Bathymodiolus sp. mussel from a methane seep on the Gabon continental margin (southeast Atlantic): 16S rRNA phylogeny and distribution of the symbionts in gills. Appl. Environ. Microbiol. 71, 1694-1700. 
Duperron, S., Sibuet, M., MacGregor, B.J., Kuypers, M.M.M., Fisher, C.R., Dubilier, N., 2007. Diversity, relative abundance and metabolic potential of bacterial endosymbionts in three Bathymodiolus mussel species from cold seeps in the Gulf of Mexico. Environ. Microbiol. 9, 1423-1438.

Felbeck, H., 1981. Chemoautotrophic potential of the hydrothermal vent tube worm, Riftia pachyptila Jones (Vestimentifera). Science 213, 336-338.

Fiala-Medioni, A., McKiness, Z.P., Dando, P., Boulegue, J., Mariotti, A., Alayse-Danet, A.M., Robinson, J.J., Cavanaugh, C.M., 2002. Ultrastructural, biochemical, and immunological characterization of two populations of the mytilid mussel Bathymodiolus azoricus from the Mid-Atlantic Ridge: evidence for a dual symbiosis. Mar. Biol. 141, 1035-1043.

Fisher, C.R., Brooks, J.M., Vodenichar, J.S., Zande, J.M., Childress, J.J., Jr., R.A.B., 1993. The cooccurrence of methanotrophic and chemoautotrophic sulfur-oxidizing bacterial symbionts in a deep-sea mussel. Mar. Ecol. 14, 277-289.

Halary, S., Riou, V., Gaill, F., Boudier, T., Duperron, S., 2008. 3D FISH for the quantification of methane- and sulphur-oxidizing endosymbionts in bacteriocytes of the hydrothermal vent mussel Bathymodiolus azoricus. ISME J. 2, 284-292.

Johnson, K.S., Beehler, C.L., Sakamoto-Arnold, C.M., Childress, J.J., 1986. In situ measurements of chemical distributions in a deep-sea hydrothermal vent field. Science 231, 1139-1141.

Johnson, K.S., Childress, J.J., Beehler, C.L., Sakamoto, C.M., 1994. Biogeochemistry of hydrothermal vent mussel communities: the deep-sea analogue to the intertidal zone. Deep Sea Res. I 41, 993-1011.

Jones, H.D., Richards, O.G., Southern, T.A., 1992. Gill dimensions, water pumping rate and body size in the mussel Mytilus edulis L. J. Exp. Mar. Biol. Ecol. 155, 213-237.

Kádár, E., Bettencourt, R., Costa, V., Santos, R.S., Lobo-da-Cunha, A., Dando, P., 2005. Experimentally induced endosymbiont loss and re-acquirement in the hydrothermal vent bivalve Bathymodiolus azoricus. J. Exp. Mar. Biol. Ecol. 318, 99-110.

Karl, D.M., Wirsen, C.O., Jannasch, H.W., 1980. Deep-Sea primary production at the galapagos hydrothermal vents. Science 207, 1345-1347.

Le Bris, N., Duperron, S., 2010. Chemosynthetic communities and biogeochemical energy pathways along the Mid-Atlantic Ridge: the case of Bathymodiolus azoricus, in: Rona, P.A., Devey, C.W., Dyment, J., Murton, B.J. (Eds.), Diversity Of Hydrothermal Systems On Slow Spreading Ocean Ridges. American Geophysical Union, pp. 409-429.

Le Bris, N., Zbinden, M., Gaill, F., 2005. Processes controlling the physico-chemical microenvironments associated with Pompeii worms. Deep Sea Res. I 52, 1071-1083.

Lesser, M.P., 2011. Coral Bleaching: Causes and Mechanisms, in: Dubinsky, Z., Stambler, N. (Eds.), Coral reefs: an ecosystem in transition. Springer Netherlands, pp. 405-419.

Lorion, J., Halary, S., Nascimento, J. do, Samadi, S., Couloux, A., Duperron, S., 2012. Evolutionary history of Idas sp. Med (Bivalvia: Mytilidae), a cold seep mussel bearing multiple symbionts. Cah. Biol. Mar. 53, 77-87.

Petersen, J.M., Zielinski, F.U., Pape, T., Seifert, R., Moraru, C., Amann, R., Hourdez, S., Girguis, P.R., Wankel, S.D., Barbe, V., Pelletier, E., Fink, D., Borowski, C., Bach, W., Dubilier, N., 2011. Hydrogen is an energy source for hydrothermal vent symbioses. Nature 476, 176-180.

Prosser, J.I., 2010. Replicate or lie. Environ. Microbiol. 12, 1806-1810.

Pruski, A.M., Fiala-Médioni, A., 2003. Stimulatory effect of sulphide on thiotaurine synthesis in three hydrothermal-vent species from the East Pacific Rise. J. Exp. Biol. 206, 2923-2930.

R Development Core Team, 2013. R Development Core Team (2013). R: A language and environment for statistical computing. R Foundation for Statistical Computing, Vienna, Austria. ISBN 3-900051-07-0, URL http://www.R-project.org.

Riou, V., Duperron, S., Halary, S., Dehairs, F., Bouillon, S., Martins, I., Colaço, A., Serrão Santos, R., 2010. Variation in physiological indicators in Bathymodiolus azoricus (Bivalvia: Mytilidae) at the Menez Gwen Mid-Atlantic Ridge deep-sea hydrothermal vent site within a year. Mar. Environ. Res. 70, 264-271. 
Riou, V., Halary, S., Duperron, S., Bouillon, S., Elskens, M., Bettencourt, R., Santos, R.S., Dehairs, F., Colaço, A., 2008. Influence of $\mathrm{CH}_{4}$ and $\mathrm{H}_{2} \mathrm{~S}$ availability on symbiont distribution, carbon assimilation and transfer in the dual symbiotic vent mussel Bathymodiolus azoricus. Biogeosciences 5, 1681-1691.

Shillito, B., Gaill, F., Ravaux, J., 2014. The Ipocamp pressure incubator for deep-sea fauna. J. Mar. Sci. Technol.-Taiwan 22, 97-102.

Shillito, B., Hamel, G., Duchi, C., Cottin, D., Sarrazin, J., Sarradin, P.-M., Ravaux, J., Gaill, F., 2008. Live capture of megafauna from $2300 \mathrm{~m}$ depth, using a newly designed pressurized recovery device. Deep Sea Res. I 55, 881-889.

Thurber, R.V., Willner-Hall, D., Rodriguez-Mueller, B., Desnues, C., Edwards, R.A., Angly, F., Dinsdale, E., Kelly, L., Rohwer, F., 2009. Metagenomic analysis of stressed coral holobionts. Environ. Microbiol. 11, 2148-2163.

Trask, J.L., Van Dover, C.L., 1999. Site-specific and ontogenetic variations in nutrition of mussels (Bathymodiolus sp.) from the Lucky Strike hydrothermal vent field, Mid-Atlantic Ridge. Limnol. Oceanogr. 44, 334-343.

Van Dover, C., 2000. The ecology of deep-sea hydrothermal vents. Princeton University Press, Princeton, N.J.

Van Dover, C.L., German, C.R., Speer, K.G., Parson, L.M., Vrijenhoek, R.C., 2002. Evolution and biogeography of deep-sea vent and seep invertebrates. Science 295, 1253-1257.

Von Cosel, R., Cosel, R.V., Comtet, T., Krylova, E.M., 1999. Bathymodiolus (Bivalvia: Mytilidae) from hydrothermal vents on the Azores Triple Junction and the Logatchev Hydrothermal Field, Mid-Atlantic Ridge. Veliger 42, 218-248.

Von Cosel, R., Salas, C., Høisæter, T., 2001. Vesicomyidae (Mollusca: Bivalvia) of the genera Vesicomya, Waisiuconcha, Isorropodon and Callogonia in the eastern Atlantic and the Mediterranean. Sarsia 86, 333-366.

Wallner, G., Amann, R., Beisker, W., 1993. Optimizing fluorescent in situ hybridization with rRNAtargeted oligonucleotide probes for flow cytometric identification of microorganisms. Cytometry 14, 136-143.

Wentrup, C., Wendeberg, A., Schimak, M., Borowski, C., Dubilier, N., 2014. Forever competent: Deep-sea bivalves are colonized by their chemosynthetic symbionts throughout their lifetime. Environ. Microbiol. 16, 3699-3713. 


\begin{tabular}{|c|c|c|c|c|c|c|c|}
\hline Probe & Target & Sequence [5' $\rightarrow$ 3'] & Cy3 & Cy5 & FITC & Channel colour & Reference \\
\hline EUB_338 & Eubacteria & GCTGCCTCCCGTAGGAGT & + & + & + & red & Amann et al. , 1990 \\
\hline Imed_M-138 & MOX & ACCATGTTGTCCCCCACTAA & + & - & - & green & Duperron et al. , 2008 \\
\hline Bang_T-642 & SOX & CCTATACTCTAGCTTGCCAG & - & + & - & blue & Duperron et al. , 2005 \\
\hline NON_338 & negative control & ACTCCTACGGGAGGCAGC & + & + & - & - & Wallner et al. , 1993 \\
\hline
\end{tabular}




\begin{tabular}{|c|c|c|c|c|c|}
\hline \multicolumn{2}{|c|}{ Site } & \multicolumn{2}{|c|}{ Menez Gwen } & \multicolumn{2}{|c|}{ Rainbow } \\
\hline \multicolumn{2}{|c|}{ Point } & \multicolumn{2}{|c|}{ MG2 } & \multicolumn{2}{|c|}{ France 5} \\
\hline \multicolumn{2}{|c|}{ Depth } & \multicolumn{2}{|c|}{$830 \mathrm{~m}$} & \multicolumn{2}{|c|}{$2270 \mathrm{~m}$} \\
\hline \multicolumn{2}{|c|}{ Position } & \multicolumn{2}{|c|}{$37^{\circ} 50.669 \mathrm{~N} 31^{\circ} 31.156 \mathrm{~W}$} & \multicolumn{2}{|c|}{ 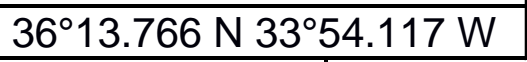 } \\
\hline \multicolumn{2}{|c|}{ Recovery mode } & BioBox & PERISCOP & BioBox & PERISCOF \\
\hline \multicolumn{2}{|c|}{ Maintained pressure } & $0 \%$ & $83.60 \%$ & $0 \%$ & $76.50 \%$ \\
\hline \multicolumn{2}{|c|}{ Number of individuals } & 7 & 10 & 3 & 16 \\
\hline \multicolumn{2}{|c|}{ Shell length mm (min- } & $32-47$ & $26.3-39$ & $88-97$ & $67-88.5$ \\
\hline \multirow{3}{*}{ 2D FISH } & $\%$ MOX & 47.2 & 44.6 & 56.3 & 57.5 \\
\hline & $\%$ SOX & 52.8 & 55.4 & 43.7 & 42.5 \\
\hline & S.D. & 5.4 & 5.1 & 6.6 & 7.6 \\
\hline \multirow{3}{*}{ 3D FISH } & $\%$ MOX & 46.5 & 44.3 & 56.3 & 56.3 \\
\hline & $\%$ SOX & 53.5 & 55.7 & 43.7 & 43.7 \\
\hline & S.D. & 5.8 & 5.7 & 6.4 & 8.3 \\
\hline \multirow{3}{*}{0 bacteriocyte } & $\%$ MOX & 48.1 & 47.5 & 56.3 & 55.6 \\
\hline & $\%$ SOX & 51.9 & 52.5 & 43.7 & 44.4 \\
\hline & S.D. & 3.8 & 4.2 & 4.6 & 6.3 \\
\hline
\end{tabular}




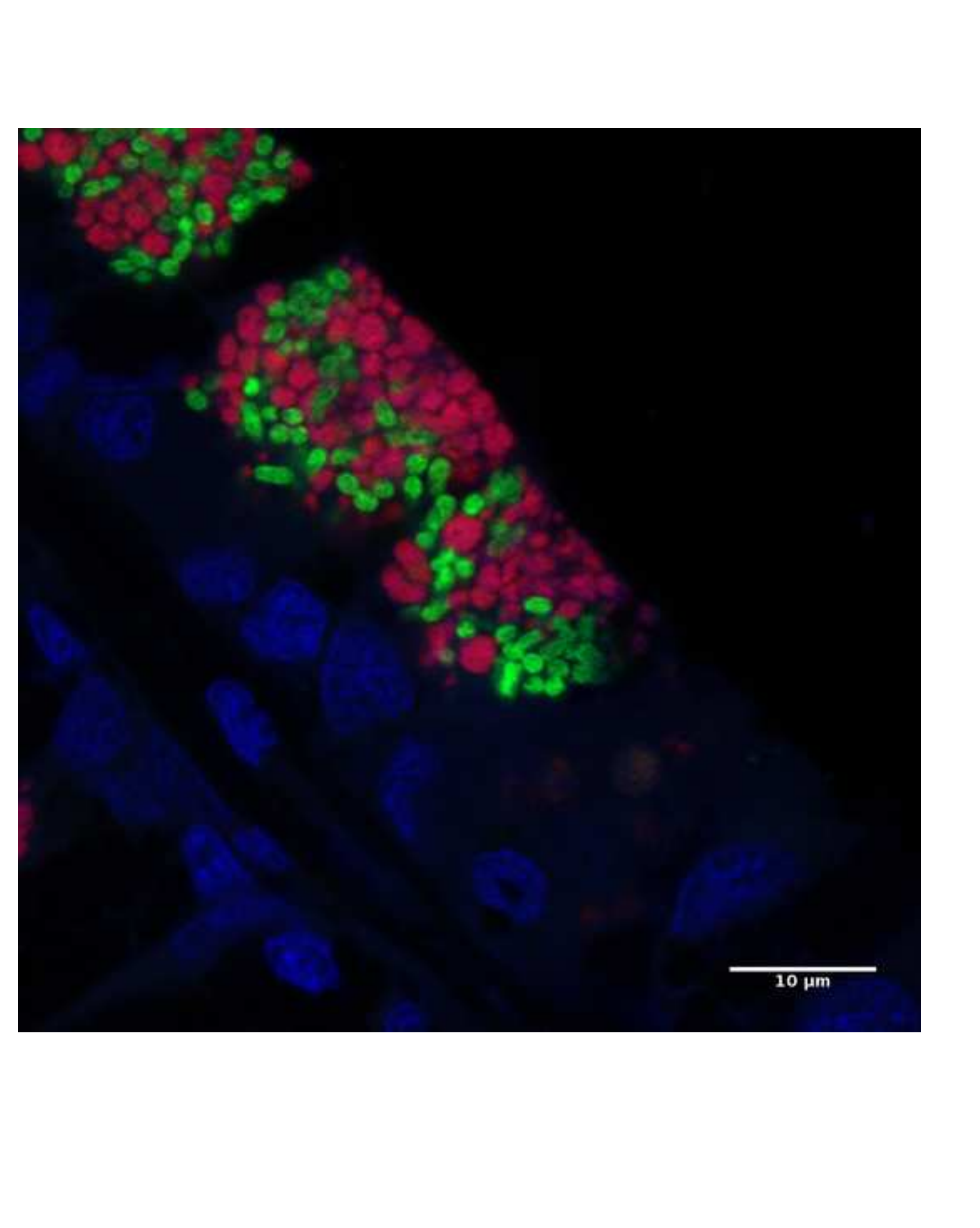

Figure 2B

\section{Figure 2B}

(1)

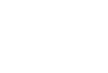
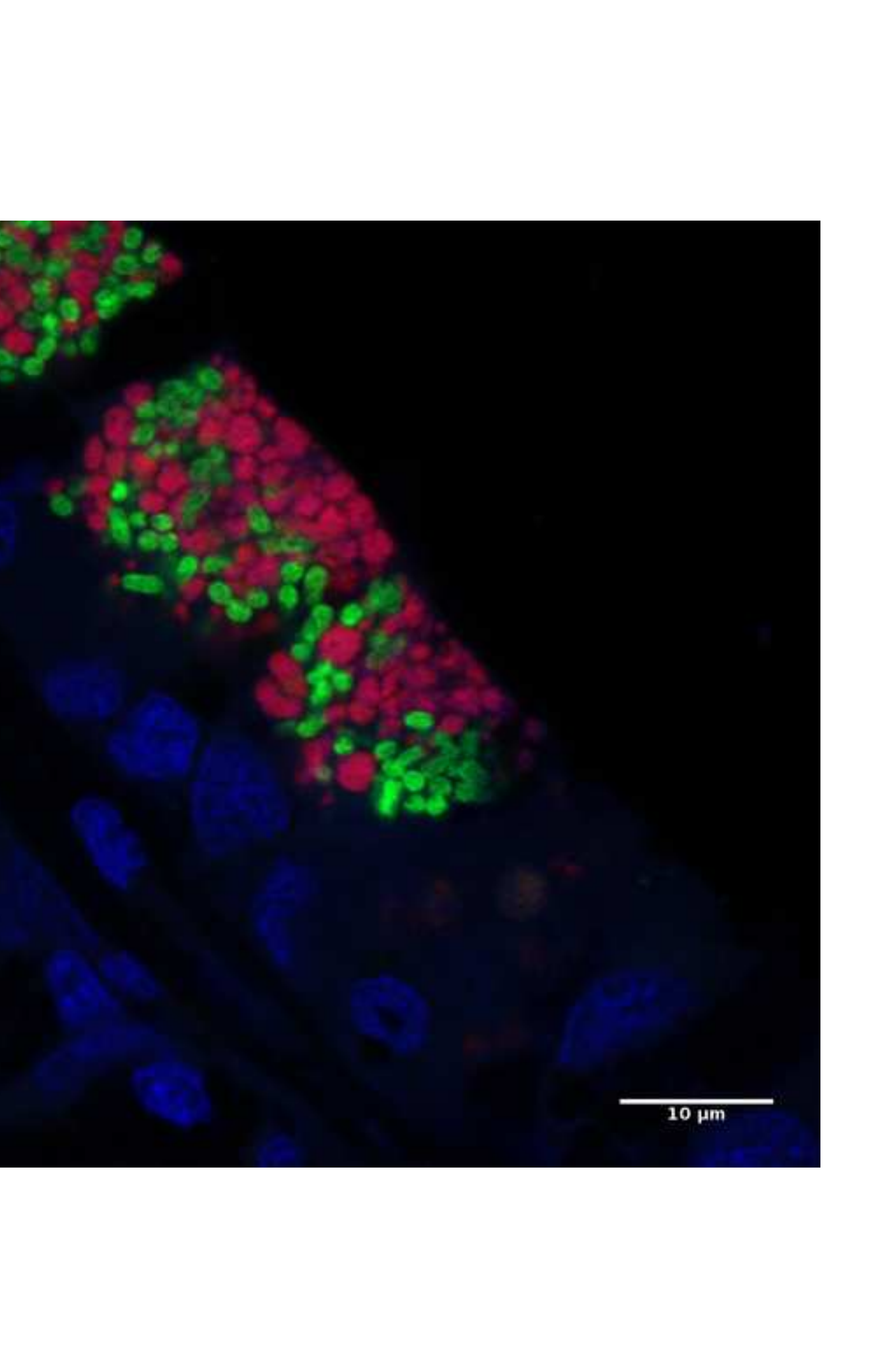

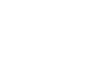

-

.

s

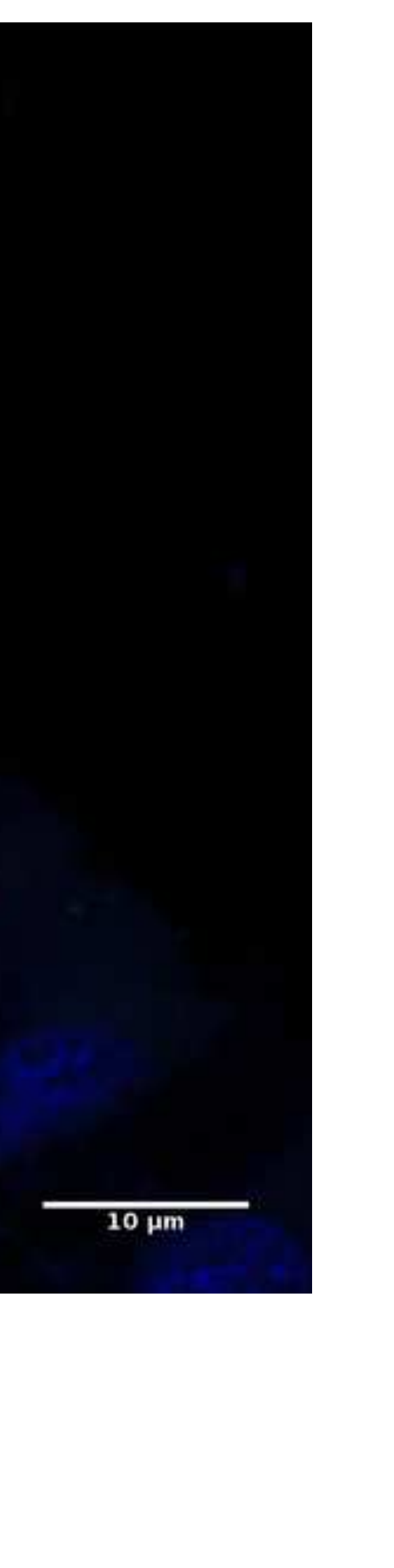




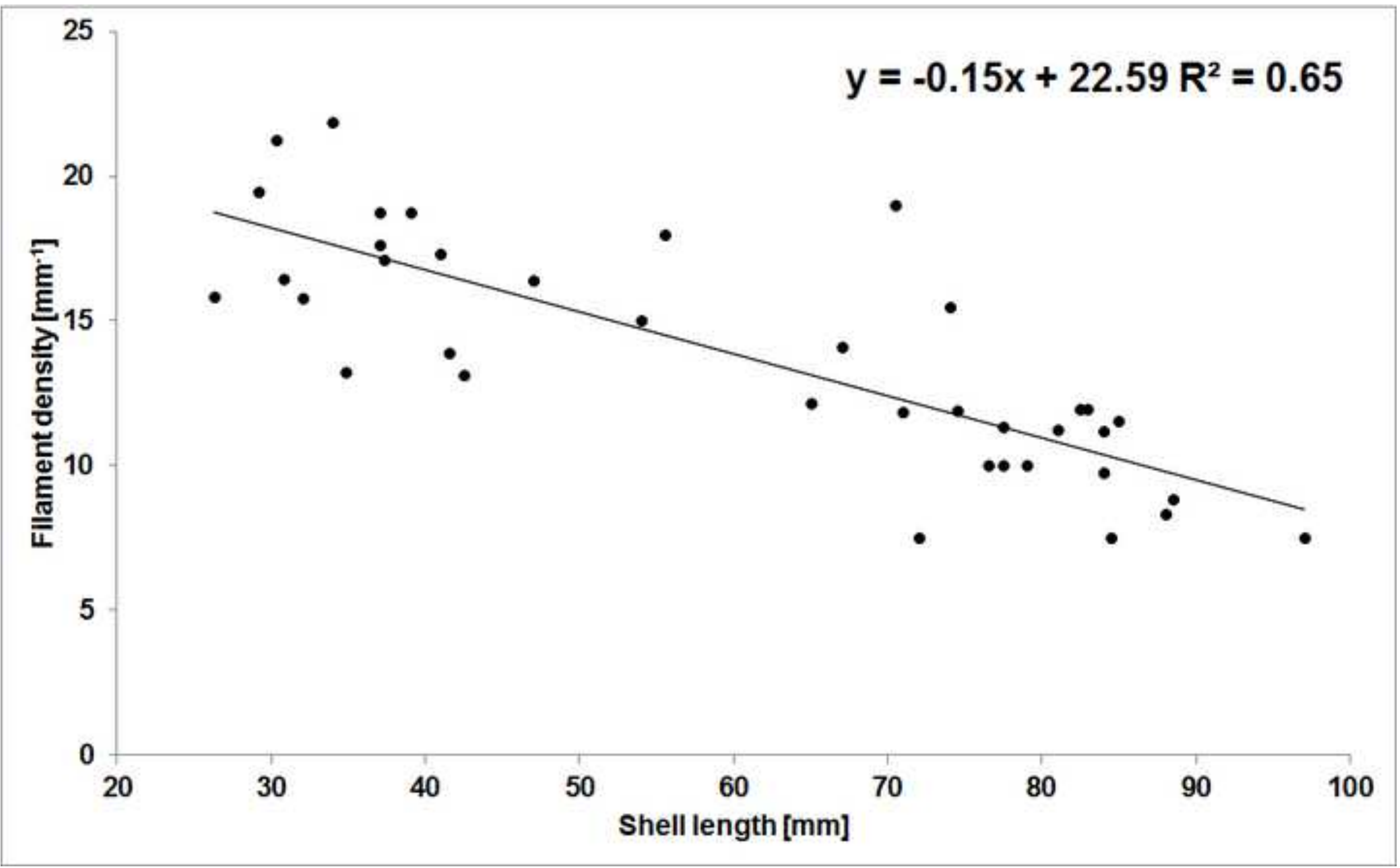




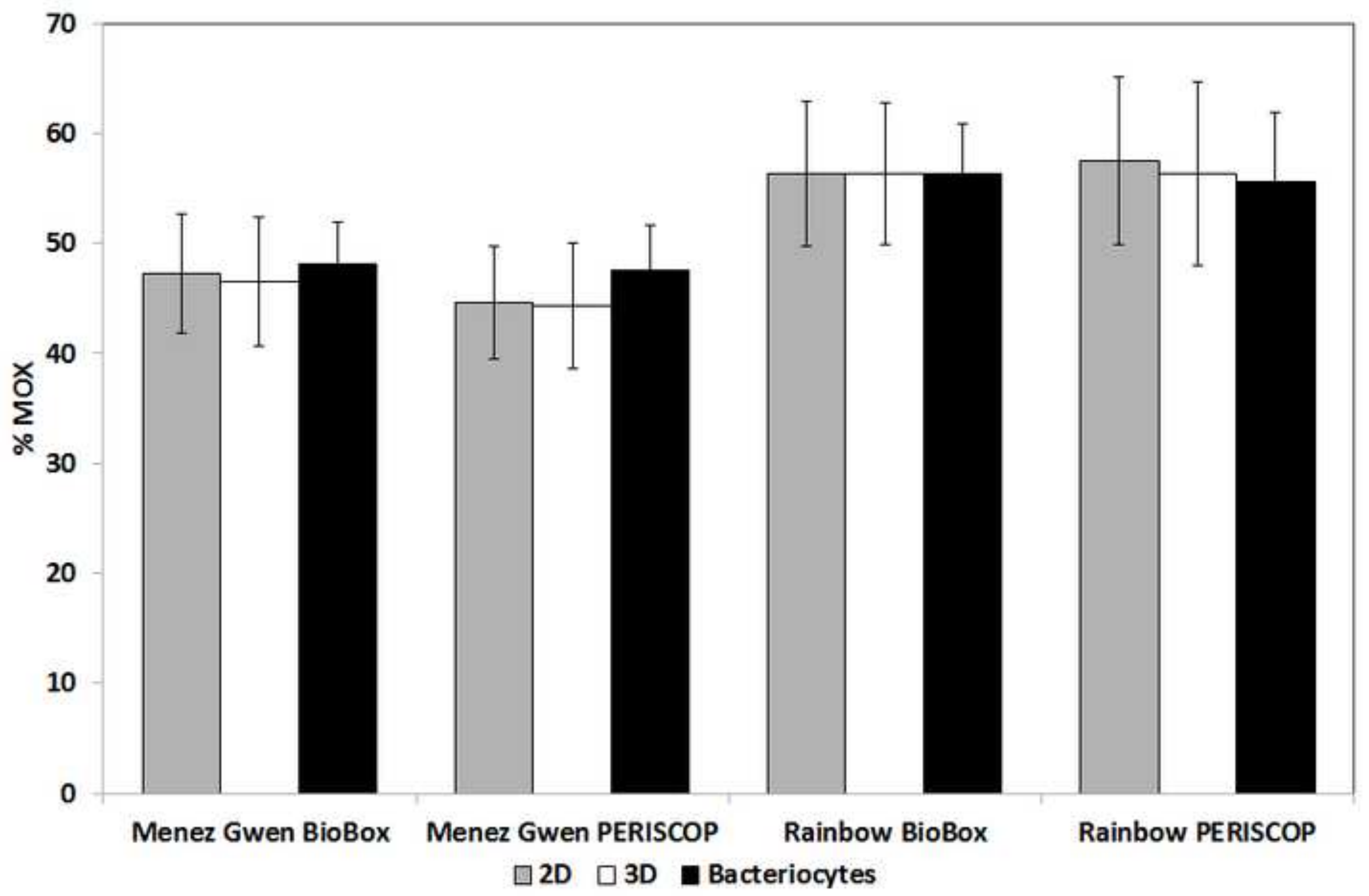




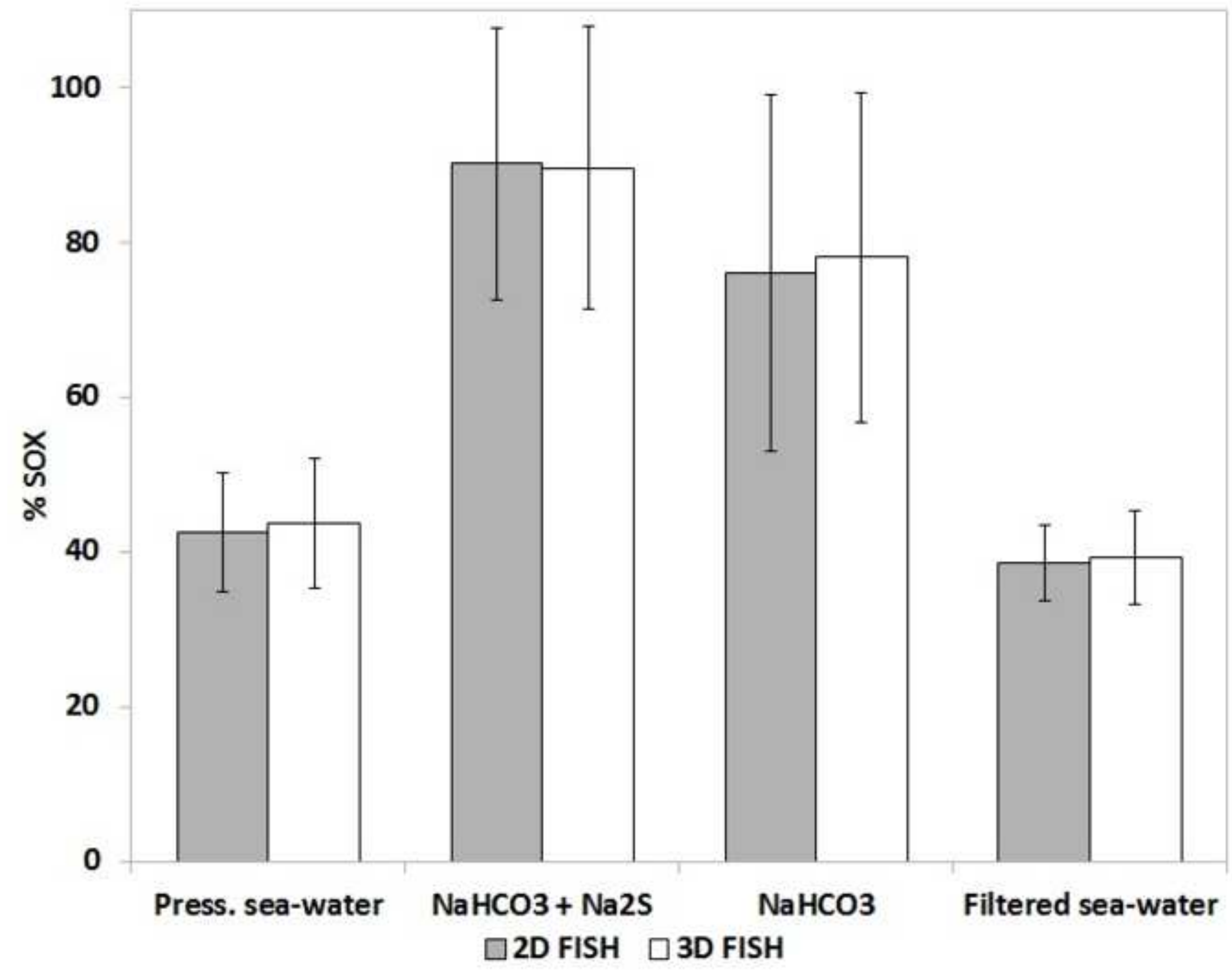

